\title{
Open-Air Biowarfare Testing AND THE Evolution of VAlues
}

\author{
Leonard A. Cole
}

The United States and the United Kingdom ended outdoor biological warfare testing in populated areas nearly half a century ago. Yet, the conduct, health effects, and propriety of those tests remain controversial. The varied views reflect the limits of currently available test information and evolving societal values on research involving human subjects. Western political culture has changed since the early days of the American and British testing programs. People have become less reluctant to question authority, and institutional review boards must now pre-approve research involving human subjects. Further, the heightened stringency of laboratory containment has accentuated the safety gap between a confined test space and one without physical boundaries. All this makes it less likely that masses of people would again be unwittingly subjected to secret open-air biological warfare tests.

$\mathrm{T}$ he United States and the United Kingdom ended outdoor biological warfare testing in populated areas nearly half a century ago. Yet, the conduct, health effects, and propriety of those tests remain controversial. The varied views reflect the limits of currently available test information and evolving societal values on research involving human subjects.

Experiments with select agents-potential biological weapons - are conducted in high-containment laboratories. Thus, bacteria such as Bacillus anthracis and Yersinia pestis (causes of anthrax and plague) are managed in laboratories with airlock access rooms, reduced inside pressure to prevent outward airflow, and filtration of exhaust air. These requirements began during the latter part of the 20th century.

In fact, biological agents deemed dangerous to humans have long received special handling. During World War II, safety measures for British workers developing anthrax weapons included protective outerwear and "meticulous technique." Structural protection consisted of a glass screen near the production machinery "to prevent gross splashing." $1(\mathrm{p} 183)$ Protection at America's military biological research facility at Fort Detrick included newly developed laboratory cabinets. Investigators would slip their hands into long rubber gloves affixed to portals, which enabled them to reach the work area. ${ }^{2}$

When an agent is released outdoors, containment precautions are literally thrown to the winds. Exposure of a population becomes subject to erratic air currents and other environmental uncertainties. Yet, several countries have engaged in extensive field testing: Japan in the 1930s and 1940 s (including torturous killing of human subjects) ${ }^{3}$ and the Soviet Union through the 1980s. ${ }^{4,5}$

Leonard A. Cole, PhD, is Adjunct Professor, Department of Emergency Medicine, and Director, Program on Terror Medicine and Security, Rutgers New Jersey Medical School, Newark, NJ. An earlier version of this article appeared as a chapter in Biological Threats in the 21st Century, Filippa Lentzos, ed. London: Imperial College Press; 2016.

(C) Leonard A. Cole, 2016; Published by Mary Ann Liebert, Inc. This Open Access article is distributed under the terms of the Creative Commons Attribution Noncommercial License (http://creativecommons.org/licenses/by-nc/4.0/) which permits any noncommercial use, distribution, and reproduction in any medium, provided the original author(s) and the source are credited. 
The United Kingdom and the United States began conducting open-air experiments during World War II and continued them for decades, often in collaboration with each other and with Canada. By the late 1950s, the UK had largely ended its offensive biological program, and in 1969 the United States abruptly renounced its own offensive program. Both countries helped establish the 1972 Biological Weapons Convention, which aims to universalize the ban on such weaponry. ${ }^{6}$ However, defensive measures are permitted, and Dugway Proving Ground in Utah remains a field testing location for the United States and its allies. Before the late 1970s, the US and the UK had conducted numerous open-air tests in other settings as well.

\section{The First Test Sites}

British and American researchers during World War II explored the efficacy of dozens of pathogens as warfare agents. They included the causative agents of anthrax, brucellosis, plague, tularemia, Q fever, and botulism. By the war's end, the only biological weapon produced in quantity was the UK's arsenal of 5 million anthrax-laced cattle cakes. The plan was to drop them over Germany's pastures to infect livestock. ${ }^{8}$ Although never implemented, the idea was based on field tests on the shore of Penclawdd, Wales, and on Gruinard Island, a small landmass off the northwest coast of Scotland. ${ }^{1}$

After the Gruinard testing ended, scientists repeatedly sought to decontaminate the island but were unsuccessful. The anthrax spore count remained high, and people were forbidden to land there. In the mid-1980s scientists found that only 3 of Gruinard's 522 acres were heavily contaminated. Massive quantities of seawater and formaldehyde were applied to those and adjacent areas, and in 1990 Gruinard was deemed safe for human return. ${ }^{9}$ The Gruinard experience confirmed both the lethality and durability of anthrax bacilli.

American field testing during the war was limited. The main intended test location, Horn Island off the Mississippi Gulf Coast, opened in October 1943. Nine months later, after winds were found predominantly blowing toward the mainland, the island facility was closed. ${ }^{10}$ In January 1945 , the biological testing area at Dugway was completed, but activity there was brief. As the war was coming to an end, the British and American biological programs were reduced and Dugway was closed. In 1948, however, a presumed Soviet biological threat prompted reinvigoration of the American and British programs.

\section{UK Field Testing During the Cold War}

The British response included open-air tests with pathogens, at sea. Between 1948 and 1954, 5 trials were conducted in waterways around the UK and in the Caribbean region. Ships towed pontoons and dinghies that carried caged monkeys, sheep, and guinea pigs. Personnel in protective outerwear sprayed select agents or detonated agent-filled bombs in the direction of the trailing animals. The released agents included B. anthracis and $Y$. pestis as well as Brucella suis and Francisella tularensis (causes of brucellosis and tularemia). ${ }^{11}$

The purpose was to assess the effects of dispersal methods and durations of exposure on the animals. As indicated in one of the trial reports, "biological efficacy of a [bacterial] cloud ... is expressed as the dosage required to give $50 \%$ infection [I/D50] or lethality [L/D50]."12(p2) Many technical details of the findings remain unavailable, including the number of animals that became infected or died. Various trials were judged to be successful, partially successful, or a failure. 11 "Success" meant, at the least, that many animals had become infected.

In succeeding years, the UK's biological warfare program became more oriented to defensive than offensive capabilities. By the late 1950s, rather than employing actual biological weapons, the British commonly used "simulants" in what became known as large area coverage (LAC) tests. The simulants were principally Bacillus globigii (also known as Bacillus subtilis), Escherichia coli, Serratia marcescens, and the chemical zinc cadmium sulfide. ${ }^{11,13}$

The earlier trials with actual warfare agents had been conducted at some distance from population locations. With a shift to large area testing, a simulant could blanket an inland area of more than 1,000 square miles. ${ }^{11,14}$

Between 1955 and 1977, simulants were repeatedly sprayed from aircraft, ships, and land generators. When released along the south coast of England, these agents reached several population centers. Additional tests with simulants were conducted in variously located cities, including London, Norwich, Southampton, and Salisbury. During the 22-year period, millions of Britons were unwittingly exposed to the test agents, which demonstrated the country's vulnerability to a biological attack. ${ }^{13}$

\section{US Field Testing During the Cold War}

The British and American open-air experiments were similar. They tested the effects of the same pathogens, used the same simulants, and employed comparable scenarios. American scientists participated in the early British Caribbean trials in part to gain experience for future US seabased tests. ${ }^{10}$ Thus, shipboard activity was similar when, in 1964, 5 US boats sailed in a 100-mile-long line off the Johnston Island atoll in the Pacific, carrying monkeys. With boat crews in sealed quarters, an airplane sprayed the path with the select agents $F$. tularensis and Coxiella burnetti (the cause of Q fever). Four years later, in 1968, a similar US test was conducted near Eniwetok, another Pacific atoll, using Staphylococcal enterotoxin B, a cause of debilitating illness. The tests were part of Project SHAD: Shipboard Hazards and Defenses. 
From 1963 to 1973, SHAD included 52 sets of tests, many involving multiple releases of biological or chemical agents in locations as far-ranging as the Deseret Test Center (80 miles from Dugway), Hawaii, the Panama Canal Zone, and off the coast of San Diego. Besides the 3 microbes cited above (F. tularensis, Coxiella burnetti, Staphylococcal enterotoxin $B$ ), open-air releases included the nerve agents sarin, tabun, soman, and VX. One or more of these potential biological or chemical weapons were used in 26 SHAD tests. Biological simulants were also released: B. globigii in 24 tests, S. marcescens in 7 tests, and E. coli in 5 tests. ${ }^{10,15}$

The public first learned about Project SHAD at congressional hearings in 2002, more than 50 years after its implementation. ${ }^{16,17}$ The belated disclosures were especially surprising because 25 years earlier the Army had acknowledged other 1950s and 1960s germ warfare tests and had made no mention of SHAD. At 1977 Senate hearings, army witnesses disclosed that from 1949 to 1969, 239 open-air tests were conducted in populated areas throughout the United States. Unlike SHAD, the previously revealed tests used only simulants, mainly $S$. marcescens $(\mathrm{SM})$, B. globigii (BG), and the chemical zinc cadmium sulfide (FP, for fluorescent particles). ${ }^{18}$

\section{Aims of the Field Tests}

Reports about several of the UK and US open-air tests eventually were in part declassified. The purpose of a test, stated or implied, was to assess any of the following:

- Effects of environmental conditions on released agents $\circ$ over water vs land

○ daytime brightness vs night darkness

- sunlight (ultraviolet) vs cloudy condition

o weather variations including temperature, wind velocity and direction, humidity

- Ability of specific agents to cause illness and death

- Dispersion patterns of agents after release

- Survivability of released microbes

- Vulnerability of particular target areas: subways, city streets, open land

- Effectiveness of various methods of delivery: munitions, air blowers/generators, hand sprayers

- Effectiveness of various protective measures

The tests expanded knowledge in all these areas. They demonstrated, for example, that brucella organisms packed in bomblets could survive a detonation and infect animals a mile from the point of release. ${ }^{10}$ Also, agents could spread over great distances. An airplane flying from South Dakota to Minnesota released FP that was later detected 1,200 miles away. ${ }^{19,20}$ Still, even after years of research, few biological weapons had been produced and stockpiled. From a 1969 report, the year that the United States renounced its offensive program: "No large inventory of dry (powdered) anti- personnel lethal or incapacitating biological agents is maintained and only eight aircraft spray disseminators are in the inventory." ${ }^{21(\mathrm{p} 34)}$ Historian John Moon concluded that a key reason for the meager stockpile was that the use of these weapons could result in "unpredictable consequences."

The stubborn resistance of anthrax spores to decontamination efforts on Gruinard Island was a prime example of an unexpected consequence. Another occurred during a British sea operation in 1952, when a fishing vessel strayed into a cloud of plague bacteria near the northern Scottish island of Lewis. After no cases of infection were reported, most records of the incident were destroyed. ${ }^{11}$

In the United States, after the secret spraying of San Francisco with SM in 1950, 11 patients at a city hospital contracted serratia infections, one of whom died. The army deemed the outbreak a coincidence and continued to use SM as a simulant in subsequent open-air tests. ${ }^{22}$

Through the years, the Americans and British explored numerous ways that a biological attack might be launched. A list of scenarios and simulants used in several US tests is illustrative:

- 1950: release by seaborne generators blowing from a boat offshore toward San Francisco: SM, BG, FP. ${ }^{22,23}$

- 1953: release by land-based and rooftop-based generators in Minneapolis: FP. ${ }^{24}$

- 1953: release from automobiles moving in traffic in Minneapolis and St. Louis: FP. ${ }^{25}$

- 1956: release of Aedes aegypti mosquitoes, vectors for the yellow fever virus, in Savannah, Georgia. The test mosquitoes were uninfected females, and the aim was to estimate "how many mosquitoes entered houses and

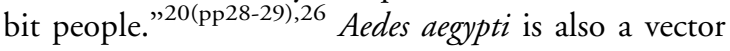
for other viruses, including the Zika virus, a causative disease agent of much current concern in the Americas. Whether US testing included additional releases of the species and substantially added to the mosquito population is unknown.

- 1957-1958: continuous release from airplanes during large-area coverage flights "from the Rockies to the Atlantic, from Canada to the Gulf of Mexico": FP. ${ }^{19,20,27}$

- 1965: release by "minigenerators" hidden in briefcases at Washington, DC, National Airport and Greyhound bus terminals: BG. Previous tests in Washington, in 1949 and 1950, used SM. ${ }^{18,28}$

- 1966: release from light bulbs, filled with simulant, tossed on subway tracks as trains approached stations, New York City: BG. ${ }^{29,30}$

In addition to these scenarios, various explosive and other aerosol dissemination methods were investigated during the decades of American and British testing. Yet, for all the inventiveness of the scenarios, none included widespread dispersal of an agent by mail, which is how the only actual large-scale biological assault was launched in either country. ${ }^{30,31}$ 
In the fall of 2001, about a half-dozen letters containing powdered anthrax spores were mailed to American political and media figures. Powder leaking from the letters killed 5 people, sickened 17, and necessitated prophylactic antibiotics for 30,000 others. More than a month passed before it was recognized that scores of buildings had also been contaminated, some of which remained shut for years. Ironically, a study of BG released from envelopes was conducted in a confined space months before the anthrax letters attack. But it did not foretell the massive crosscontamination by leaked spores that occurred during postal processing. ${ }^{30,32}$ The many years of field testing had done little to help prepare for an attack via the US mail.

\section{When the Public Found Out}

The belated disclosures about the open-air tests drew charges that simulants as well as select agents had caused previously unexplained illnesses. People from targeted areas-San Francisco, Minneapolis, St. Louis, Puerto Rico, Dorset (England) - sued the government or demanded investigations to validate their health claims. ${ }^{13,22,33-35}$ Neither subsequent studies nor court cases confirmed that the tests had caused illness. In fact, establishing a correlation 30 to 50 years after an event complicates the search. The continued murkiness of the issue was evident in a 2007 study that found no patterns of ill health among 5,500 veterans involved in SHAD. The study warned that the "findings should not be misconstrued as clear evidence that there are no possible long-term health effects related to SHAD involvement." 36

In 2016, the Institute of Medicine reported on a followup study, titled SHAD II. Its summary stated:

The SHAD II analysis found no clear differences in degree of illness between SHAD participants and the comparison group. This result was consistent with the absence of differences in self-reported hospitalizations noted in SHAD I, but not in accord with the SHAD I survey responses that indicated overall worse health among SHAD veterans. ${ }^{37(\mathrm{p} 1)}$

This assessment will likely not satisfy skeptics. Available evidence appears unable to prove absolutely that the SHAD project did or did not affect participants' health. Barring surprise revelations, the passage of time will further diminish the opportunity to access information about a longpast event. Documents are lost or destroyed, memories fade, and key people are no longer reachable. Even with documents in hand that recapitulate an event, they are unlikely to convey the full context of a 50-year-old experience. Societal values change over time and behaviors once considered acceptable are now deemed objectionable, which certainly has been the case of research involving human subjects.

\section{Evolving Ethical Norms}

The 1947 trial verdict against German doctors who conducted ghastly experiments on concentration camp prisoners included a section known as the Nuremberg Code. A key tenet of the code holds that experiments on human subjects require their informed consent. Although the Nuremberg Code was adopted by the US military, its implementation evolved over time. When the army began open-air biological testing in 1949, the code seemed of little concern to the testers or their commanders. They presumed the test agents to be harmless, and the millions of people exposed were not deemed experimental subjects. Both suppositions are debatable, but at that time challenging authority was less a cultural norm than in subsequent decades.

In the 1970s, the public learned that other government agencies had also been performing experiments on unwitting subjects. The US Public Health Service had given fake medicine to hundreds of syphilitic black men, and the Central Intelligence Agency had laced the drinks of unsuspecting people with mind-altering chemicals. Besides the unknowing participants in biological warfare tests, massive numbers had also become unwitting subjects in chemical and nuclear tests. Numerous military personnel were exposed to mustard and nerve agents in experiments for which they might receive extra leave time but little information about the potential danger of their exposures. ${ }^{38}$ Similarly unaware of the risks, thousands of soldiers had been subjected to increased radiation in drills after nuclear detonations at Nevada test sites. Many more thousands of civilians were unwittingly dosed with radiation downwind from the tests. ${ }^{39}$

Such belatedly revealed information prompted federal legislation that mandated the establishment of review boards to oversee an institution's research involving human subjects. ${ }^{40}$ The new law was an expression of growing sensitivity to the rights of individuals in relation to authority.

The evolving ethos extended beyond individuals who were research subjects. The physician-patient relationship was also affected. The traditional model of medical paternalism had permitted the withholding of information from patients or even lying to them about treatment decisions. ${ }^{41}$ In 1981, for the first time, the American Medical Association stated: "Informed consent is a basic policy in both ethics and law that physicians must honor." ${ }^{42}$ The physician has an "ethical obligation" to provide a patient with all medically reasonable treatment alternatives, to help the patient make an informed choice. ${ }^{42}$

Broadened sensitivity about open-air testing was also demonstrated more recently. In 2013 the New York City Police Department and Brookhaven National Laboratories were transparent about an airflow study they intended to conduct in the subway and streets. The release of perfluorocarbon tracer gases would enable a better understanding 
of the risks of airborne contaminants, including biological agents. Based on decades of experience with this tracer, Brookhaven scientists maintained that it presented no danger to humans. ${ }^{43}$

Several features of the 2013 exercise differed from those of the army's 1966 subway test:

- The tracer in 2013 was an inert substance with a long safety record rather than live bacteria (B. globigii), which were used in 1966 . Those bacteria, while relatively harmless, posed a danger to individuals with weakened immune systems or who were otherwise in poor health.

- The nature and planned dates of the 2013 test were described in advance by the police department, and the information was broadly reported by local mediatelevision, radio, print, and online. The 1966 study had been conducted in secret.

- By informing the public in advance of the 2013 exercise, authorities could respond to people's questions about the conduct, goals, and safety of the tests.

- Few individuals raised concerns, and the tests were conducted without protest.

- The culture shift since the army's earlier testing program was evident in a statement by a police department spokesman: "There was never any thought of conducting the tests without announcing them in advance." 44

These observations suggest that the attentive public's response was one of tacitly informed consent. Of course, implied consent lacks the specificity of a signed agreement by a human research subject. But the concept has also been embraced in other areas of research. A recent example was a study of the effectiveness of differing blood products by administering them to unconscious emergency trauma patients. ${ }^{45}$

Unlike the army's secret tests, authorities in 2013 offered full and frank disclosures in advance of the subway exercise. The police provided a telephone number and website for further information. Few if any of the city's residents, elected officials, health authorities, or media outlets raised objections. Indeed, contemporary cultural values leave no room for secret open air testing that might endanger unwitting participants.

\section{Unpredictable Path of a Disease Outbreak}

The unintended consequences of biological warfare testing are a subset of uncertain outcomes of disease outbreaks in general. Flawed assumptions about the nature and extent of epidemics have often led to erroneous predictions. Nowhere is this better illustrated than with the recent Ebola experience in Africa. Although the virus is deemed a potential biological weapon, the outbreak was of natural origin.
The Ebola virus was first identified as a disease agent in 1976 when it infected 318 victims in Zaire, 280 of whom died. Occasional Ebola outbreaks later occurred in other African countries, though the number of infected individuals never exceeded a few hundred in a single year. In mid2014, as if from nowhere, Ebola cases began to multiply in Guinea, Sierra Leone, and Liberia. Additional cases were reported elsewhere in Africa and in Spain, Italy, the United Kingdom, and the United States. The initial medical response by the World Health Organization (WHO) was inadequate and chaotic. ${ }^{46}$

By September, the US Centers for Disease Control and Prevention (CDC) estimated that in Sierra Leone and Liberia at least 8,000 Ebola cases had developed in the previous 6 months. The disease seemed on a rampage, and the CDC made this startling assessment:

Without additional interventions or changes in community behavior, CDC estimates that by January 20, 2015, there will be a total of approximately 550,000 Ebola cases in Liberia and Sierra Leone or 1.4 million if corrections for underreporting are made. ${ }^{47}$

Yet, soon after this forecast, the number of new Ebola infections dwindled dramatically. By January 20, 2015, rather than the predicted half million or 1.4 million, the actual number of cases was about $21,000 .^{48}$

Neither additional interventions nor changes in community behavior in the last 3 months of 2014 could explain the enormous gap between the projected and real numbers of Ebola cases. The course of any disease outbreak may be affected by imponderables: weather, development of herd immunity, genetic mutations of the causative organism, incidence patterns that veer from past trend lines. The reasons for the unexpected drop in additional Ebola cases were not clear. Except for a slight increase of new cases in June 2015, the downward trend continued throughout that year. The WHO reported the absence of any new cases in January 2016, and the epidemic seemed to have run its course. The grand total of Ebola cases in 2014-15 was 28,542, including 11,299 deaths. ${ }^{49}$

The WHO and CDC were faulted at both ends of the outbreak: for inadequate preparedness at the beginning and wrong estimates about the severity of the outcome. Efficient care at the outset would surely have meant fewer infected individuals. But even if medical resources had been more quickly mobilized, the epidemic would have taken a toll.

The Ebola episode reflects experience with the earlier biological warfare tests. Once a microorganism attains an environmental niche, outcomes become uncertain. As with anthrax spores on Gruinard Island or Ebola-infected humans in Liberia and Sierra Leone, anticipated outcomes may be thwarted by the capriciousness of microbial behavior.

No sooner had the Ebola scare abated than a new biological threat, posed by the Zika virus, had erupted. The effects of Zika could be severe, especially among 
pregnant women, whose newborns seemed more likely to have microcephaly-small brain-damaged heads.

The spread of the Zika virus, mainly in the Americas, was as sudden as that of Ebola 2 years earlier. In January 2016, the WHO predicted 3 or 4 million Zika cases by the end of the year, though without revealing the basis for the estimate. ${ }^{50}$ Whether this forecast proves more accurate than that for Ebola awaits the unfolding of events. In addition to the microbial imponderables already noted, Zika effects might also be mediated by new technical advances or other innovative countermeasures.

Experience with past outbreaks, whether natural or human-caused, suggests the need for caution with predictions about how and when a biological threat will end. It also is a reminder of the potential danger posed by past open-air tests with real or simulated biological weapons.

\section{Conclusion}

Large sections of available reports on the British and American open-air biological warfare tests have been redacted. Still, several readable pages are replete with data. They often include details about how, when, and where an agent was disseminated and about the results of the trial. But the open-air programs also left a legacy of unintended consequences, including lawsuits against the government for concealing information about the tests and their possible dangers. Moreover, the simulants $S$. marcescens and B. globigii, previously considered by some to be harmless, are now deemed human pathogens. ${ }^{36,51}$

Western political culture has changed since the early days of the American and British testing programs. People have become less reluctant to question authority, and institutional review boards must now pre-approve research involving human subjects. Further, the heightened stringency of laboratory containment has accentuated the safety gap between a confined test space and one without physical boundaries. All this makes it less likely that masses of people would again be unwittingly subjected to secret openair biological warfare tests.

\section{REFERENCES}

1. Carter B, Pearson G. British biological warfare and biological defense, 1925-45. In: Geissler E, Moon JEvC, eds. Biological and Toxin Weapons: Research, Development and Use from the Middle Ages to 1945. New York: Oxford University Press; 1999.

2. Covert NM. Cutting Edge: A History of Fort Detrick, Maryland, 1943-1993. Fort Detrick, MD: Public Affairs Office, Headquarters, US Army Garrison, Fort Detrick, MD; 1993.

3. Harris SH. Factories of Death: Japanese Biological Warfare, 1932-1945, and the American Cover Up. New York: Routledge; 1994.
4. Miller J, Engelberg S, Broad W. Germs: Biological Weapons and America's Secret War. New York: Simon and Schuster; 2001.

5. Leitenberg M, Zilinskas RA, Kuhn JH. The Soviet Biological Weapons Program: A History. Cambridge, MA: Harvard University Press; 2012.

6. Convention on the Prohibition of the Development, Production and Stockpiling of Bacteriological (Biological) and Toxin Weapons. Opened for signature April 10, 1972, and entered into force March 26, 1975. http://www.nti.org/ learn/treaties-and-regimes/convention-prohibition-developmentproduction-and-stockpiling-bacteriological-biological-andtoxin-weapons-btwcl. Accessed July 18, 2016.

7. Welcome to Dugway Proving Ground. Dugway Proving Ground website. 2016. http://www.military.com/base-guide/ dugway-proving-ground. Accessed July 18, 2016.

8. Harris R, Paxman J. A Higher Form of Killing: The Secret Story of Chemical and Biological Warfare. New York: Hill and Wang; 1982.

9. Pearson GS. Gruinard Island returns to civil use. $A S A$ Newsletter September 1990;90(5). http://www.asanltr.com/ newsletter/01-5/articles/015c.htm. Accessed July 18, 2016.

10. Regis E. Biology of Doom: The History of America's Secret Germ Warfare Project. New York: Henry Holt; 1999.

11. Balmer B. The UK biological weapons program. In: Wheelis M, Rósza L, Dando M, eds. Deadly Cultures: Biological Weapons Since 1945. Cambridge, MA: Harvard University Press; 2006:47-83.

12. UK Ministry of Defense. Operation Cauldron 1952, AC 12217, Scientific Report by the Microbiological Research Department, Porton, and Naval Report by the Naval Commander, April 1953.

13. Barnett A. Millions were in germ war tests. Guardian April 21, 2002. http://www.thegurdian.com/politics/2002/apr/21/ uk.medicalscience. Accessed July 18, 2016.

14. Norris KP. Concentration, Viability, and Immunological Properties of Airborne Bacteria Released from a Massive Line Source. UK Ministry of Defense, MRE Field Trial Report No. 3 (Trials conducted October 1963 to April 1964); 1966.

15. US Department of Defense. Project 112/SHAD Fact Sheets. Health.mil website. 2003. http://mcm.fhpr.osd.mil/cb_ exposures/project112_shad/shadfactSheets.aspx. Accessed July $18,2016$.

16. US House of Representatives. Committee on Veterans' Affairs, Subcommittee on Health. Military operations aspects of SHAD and Project 112. October 9, 2002. https://www. gpo.gov/fdsys/pkg/CHRG-107hhrg84758/pdf/CHRG107hhrg84758.pdf. Accessed July 18, 2016.

17. US Senate. Committee on Armed Services, Subcommittee on Personnel. The Department of Defense's inquiry into Project 112/Shipboard Hazard and Defense (SHAD) tests. October 10, 2002. https://www.gpo.gov/fdsys/pkg/CHRG107shrg84856/html/CHRG-107shrg84856.htm. Accessed July 18, 2016.

18. US Senate. Committee on Human Resources, Subcommittee on Health and Scientific Research. Biological testing involving human subjects by the Department of Defense. March 8 and May 23, 1977. https://archive.org/details/ biologicaltestin00unit. Accessed July 18, 2016. 
19. US Army Chemical Corps. Summary of Major Events and Problems for 1958. Historical Office Army Chemical Center, Maryland, annual reports, 1953-1962.

20. Cole LA. The Eleventh Plague: The Politics of Biological and Chemical Warfare. New York: WH Freeman; 1997.

21. Moon JEvC. The US biological weapons program. In: Wheelis M, Rósza L, Dando M, eds. Deadly Cultures: Biological Weapons Since 1945. Cambridge, MA: Harvard University Press; 2006:9-46.

22. Cole LA. Clouds of Secrecy: The Army's Germ Warfare Tests Over Populated Areas. Lanham, MD: Rowman and Littlefield; 1990.

23. US Chemical Corps Biological Laboratories. Biological Warfare Trials at San Francisco, California, 20-27 September 1950. Special Report No. 142. Camp Detrick, Frederick, MD, January 22, 1951.

24. US Army Chemical Corps. Behavior of Aerosol Clouds Within Cities. Joint Quarterly Report No. 3, January-March 1953.

25. US Army Chemical Corps. Behavior of Aerosol Clouds Within Cities. Joint Quarterly Report No. 4, July-September 1953.

26. US Army Chemical Corps. Summary of Major Events and Problems for 1959. Historical Office Army Chemical Center, Maryland, annual reports, 1953-1962.

27. Guillemin J. Biological Weapons: From the Invention of StateSponsored Programs to Contemporary Bioterrorism. New York: Columbia University Press; 2005.

28. US Army Biological Laboratories. Miscellaneous Publication 7, Study US65SP. Fort Detrick, Frederick, MD, July 1965.

29. US Army. A Study of the Vulnerability of Subway Passengers in New York City to Covert Action with Biological Agents. Miscellaneous Publication 25. Fort Detrick, Frederick, MD, January 1968.

30. Cole LA. The Anthrax Letters: A Medical Detective Story. Washington, DC: National Academies Press; 2003.

31. Cole LA, Kahn LH, Sandman PM. Bioterrorism and the communication of uncertainty. In: Cole LA, Connell ND, eds. Local Planning for Terror and Disaster: From Bioterrorism to Earthquakes. Hoboken, NJ: Wiley-Blackwell; 2012.

32. Kournikakis B, Armour SJ, Boulet CA, Spence M, Parsons B. Risk Assessment of Anthrax Threat Letters. Canada Defense R\&D Technical Report DRES TR-2001-048. September 2001. http:// www.ph.ucla.edu/epi/bioter/canadiananthraxstudysep01.pdf. Accessed July 18, 2016.

33. Worthington R. Army test raises accusations. Chicago Tribune June 15, 1994. http://articles.chicagotribune.com/1994-0615/news/9406150171_1_zinc-cadmium-sulfide-tests-sen-paulwellstone. Accessed July 18, 2016.

34. Mann J. Suit filed over government test-spraying in St. Louis during Cold War. St. Louis Post-Dispatch November 21, 2012. http://www.stltoday.com/news/local/crime-and-courts/ suit-filed-over-government-test-spraying-in-st-louis-during/ article_9bc1fc7d-7093-58a3-b557-0cbac5dc38ab.html. Accessed July 18, 2016.

35. Boudreau A, Bronstein S. Island residents sue U.S., saying military made them sick. CNN February 1, 2010. http:// www.cnn.com/2010/US/02/01/vieques.illness/. Accessed July $18,2016$.

36. Page WF, Young HA, Crawford HM; Advisory Panel for the Study of Long-Term Health Effects of Participation in Project SHAD; Medical Follow-Up Agency; Board on
Military and Veterans Health; Institute of Medicine. LongTerm Health Effects of Participation in Project SHAD (Shipboard Hazard and Defense). Washington, DC: National Academies Press; 2007.

37. Committee on Shipboard Hazard and Defense II (SHAD II); Board on the Health of Select Populations; Institute of Medicine; National Academies of Sciences, Engineering, and Medicine. Assessing Health Outcomes Among Veterans of Project SHAD (Shipboard Hazard and Defense). Washington, DC: National Academies Press; 2016. http://www.nap.edu/ catalog/21846/assessing-health-outcomes-among-veteransof-project-shad-shipboard-hazard-and-defense. Accessed July $18,2016$.

38. Schmidt U. Secret Science: A Century of Poison Warfare and Human Experiments. Oxford, UK: Oxford University Press; 2015.

39. Makhijani A, Schwartz SI. Victims of the bomb. In: Schwartz SI, ed. Atomic Audit: The Costs and Consequences of U.S. Nuclear Weapons Since 1940. Washington, DC: Brookings Institution Press; 1998.

40. National Research Act, PL 93-348, July 12, 1974. https:// history.nih.gov/research/downloads/PL93-348.pdf. Accessed July 18, 2016.

41. Buchanan A. Medical paternalism. Philosophy and Public Affairs 1978;7(4):370-390.

42. American Medical Association. Opinion. 8.08-Informed Consent. Issued 1981; updated 2006. http://www.ama-assn. org/ama/pub/physician-resources/medical-ethics/code-medicalethics/opinion808.page?. Accessed July 18, 2016.

43. New York City Police Department and Brookhaven Lab to conduct airflow study in New York City streets and subways this summer [news release]. Brookhaven National Laboratories, April 23, 2013. https://www.bnl.gov/newsroom/news .php?a=11532. Accessed July 18, 2016.

44. Dwyer J. Test gas attack is coming to the subway, this time with fair notice. New York Times May 14, 2013. http://www. nytimes.com/2013/05/15/nyregion/test-gas-attack-to-comein-subways-and-its-not-the-first.html. Accessed July 18, 2016.

45. Pragmatic, randomized optimal platelet and plasma ratios (PROPPR). University of Maryland Medical Center, Baltimore, MD. http://umm.edu/programs/shock-trauma/about/ shock-trauma-news/blood-research-study. Accessed July 18, 2016.

46. Moon S, Sridhar D, Pate MA, et al. Will Ebola change the game? Ten essential reforms before the next pandemic. The report of the Harvard-LSHTM Independent Panel on the Global Response to Ebola. Lancet 2015;3386(10009): 2204-2221.

47. Questions and answers: estimating the future number of cases in the Ebola epidemic-Liberia and Sierra Leone, 2014 2015. CDC website. September 26, 2014. http://www.cdc.gov/ vhf/ebola/outbreaks/2014-west-africa/qa-mmwr-estimatingfuture-cases.html. Accessed August 18, 2016.

48. World Health Organization. Ebola Situation Report, January 14, 2015. http://apps.who.int/iris/bitstream/10665/148237/2/ roadmapsitrep_14Jan2015_eng.pdf?ua=1\&ua=1. Accessed July 18, 2016.

49. World Health Organization. Latest Ebola outbreak over in Liberia; West Africa is at zero, but new flare-ups are likely to occur [news release]. January 14, 2016. http://www.who.int/ 


\section{OPEN-AIR BIOWARFARE TESTING}

mediacentre/news/releases/2016/ebola-zero-liberia/en/. Accessed July 18, 2016.

50. Cha AE, Sun LH. WHO: Zika virus 'spreading explosively,' level of alarm 'extremely high.' Washington Post January 28, 2016. https://www.washingtonpost.com/news/to-your-health/ $\mathrm{wp} / 2016 / 01 / 28 /$ zika-virus-who-announces-formation-ofemergency-committee-level-of-alarm-extremely-high/. Accessed July 18, 2016

51. Kurz CL, Chauvet S, Andrès E, et al. Virulence factors of the human opportunistic pathogen Serratia marcescens identified by in vivo screening. EMBO J 2003;22(7):14511460 .
Manuscript received April 7, 2016;

accepted for publication June 20, 2016.

$$
\begin{array}{r}
\text { Address correspondence to: } \\
\text { Leonard Cole, PhD } \\
\text { Adjunct Professor, Department of Emergency Medicine } \\
\text { Director, Program on Terror Medicine and Security } \\
\text { Rutgers New Jersey Medical School, Newark, NJ } \\
381 \text { Crest Road } \\
\text { Ridgewood, NJ 07450 } \\
\text { E-mail: lcole2@verizon.net }
\end{array}
$$

